\title{
Pengembangan Lembar Kerja Siswa (LKS) dengan Metode Simulasi dan Pengaruhnya Terhadap Hasil Belajar Siswa
}

\author{
Muhamamd Rapii ${ }^{1)}$, Riza Amliani ${ }^{2}$ \\ Universitas Hamzanwadi \\ Mrapii166@gmail.com
}

\begin{abstract}
ABSTRAK
Penelitian ini bertujuan untuk mengetahui: (1) proses pengembangan lembar kerja siswa dengan metode simulasi; (2) kelayakan lembar kerja siswa dengan metode simulasi menurut para ahli; (3) respon siswa terhadap penggunaan lembar kerja siswa dengan metode simulasi. Jenis penelitian ini adalah penelitian Research and Development $(R \& D)$ menggunakan model pengembangan Borg \& Gall. Instrumen utama dalam penelitian ini adalah lembar kerja siswa dengan metode simulasi untuk meningkatkan hasil belajar siswa. Teknik pengumpulan data menggunakan teknik survei dan wawancara. Teknik analisis data menggunakan analisis deskriptif kuantitatif dan diambil kesimpulan serta penggunaan uji t. Hasil penelitian menunjukkan hal-hal berikut: (1) hasil uji kelayakan tim ahli yang meliputi ahli materi, ahli bahasa, dan ahli desain diperoleh hasil validasi materi yaitu sebesar 3,62 dengan kategori layak, bahasa 3,38 dengan kategori cukup, dan desain 3,32 dengan kategori cukup. (2) hasil respon siswa terhadap terhadap lembar kerja siswa diperoleh hasil validasi materi 4,41, bahasa 3,97, dan desain 4,09 menunjukkan perolehan rata-rata skor sebesar 4,16 yang termasuk dalam kategori layak. (3) pada uji coba produk dibandingkan nilai siswa sebelum dan sesudah penggunaan LKS, nilai siswa akhir dengan rata-rata nilai awal 77,82 meningkat menjadi 82,17. Hasil Uji t yaitu thitung sebesar 2,386 dengan sig (p) $=0,01$. Sedangkan perhitungan $\mathrm{t}$ tabel diperoleh sebesar 2,073 dengan df 22 . Karena $\mathrm{t}$ thitung $\geq$ ttabel $(2,386 \geq 2,073)$ dan $\mathrm{p} \leq 0,05$ menunjukkan bahwa H0 ditolak dan Ha diterima. Hal ini menunjukkan pengembangan lembar kerja siswa dengan metode simulasi berpengaruh terhadap hasil belajar siswa mata pelajaran ekonomi.
\end{abstract}

Kata kunci: pengembangan, LKS, metode simulasi, dan pengaruhnya terhadap hasil belajar siswa.

\begin{abstract}
ABSTARCT
The objective of this research is to: (1) the process of developing student worksheets, (2) feasibilility of student worksheets with simulation method according to experts, (3) student response to the use of student worksheets with simulation method. This type of research is Research and Development (R\&D) using the Borg \& Gall model. The main instrument in this study is student worksheets with simulation methods to improve student to learning outcomes. Data collection technique use survey and interview technique. Data analysis technique using quantitative descriptive anlysis and conculision and the use of $t$ test. The result showed the following: (1) the result of the expert's team's feasibilility test which included material expert optained the result material validation that is equal to 3,62 with a decent category, 3,38 language with sufficiens category, and design 3,32 with sufficiens category, (2) the result of student responses to student worksheet obtained material validation rsults of 4,41, language 3,97, design 4,09 showed the acquisition of an average score of 4,16 which was included in the fasible category ,(3) in product trial compared to the student's score s before and after the use of worksheets, the student score with an average intia score of 74,36 increased 8,17. The $t$ test result is $t$ count of 2,386 with sig $(p)=0,01$. While the calculation of $t$ table is obtained at 2,073 with df 22 . Because tcouts $\geq$ ttable $(2,386 \geq 2,073)$ and $\mathrm{p} \leq 0,05$ indicates that $\mathrm{H0}$ is rejected and $\mathrm{Ha}$ is accepted. This shows the development of student worksheet with simulation method influential about student learning outcomes in economic subjects.
\end{abstract}

Keywords: development, students worksheet, simulation methods, and effects on student learning outcomes. 


\section{PENDAHULUAN}

Jika diamati sejauh ini, keberhasilan dalam dunia pendidikan belum dikatakan maksimal, hal ini disebabkan oleh pembelajaran yang terjadi sekarang masih bersifat satu arah. Dimana guru saja yang bersifat aktif, sedangkan siswa hanya sebagai pendengar sehingga siswa menjadi pasif, malas memperhatikan yang menyebabkan siswa kurang paham terhadap materi yang disampaikan, ini menyebabkan hasil belajar siswa kurang.

Data Badan Nasional Standar Pendidikan (BNSP) mengenai hasil ujian nasional tahun 2014/2015 menunjukan bahwa nilai daya serap hasil ujian nasional menurun dari 61,29\% menjadi 54,78\%. Untuk Provinsi NTB rata-rata nilai untuk ujian nasional mata pelajaran ekonomi adalah 5,5. Ini menunjukan bahwa hasil belajar siswa di daerah NTB khususnya pada mata pelajaran ekonomi masih tergolong rendah, hal ini juga terlihat pada nilai ujian nasional siswa.

Tabel 1. Hasil Rekap Nilai

\begin{tabular}{ccc}
\hline Jumlah siswa & Tahun & Nilai rata-rata UN \\
\hline 56 orang & 2015 & 69,59 \\
\hline 56 orang & 2016 & 62,50 \\
\hline 58 orang & 2017 & 64,30 \\
\hline
\end{tabular}

Sumber : BNSP-Rekap Hasil Nilai Ujian Nasional

Hasil tabel diatas menunjukan bahwa hasil nilai ujian siswa masih tergolong rendah, dari hasil tersebut juga menunjukan tidak adanya peningkatan hasil belajar siswa karena nilai yang didapatkan siswa masih rata-rata diangka 60. Bahkan hasil nilai dari tahun 2015 ketahun 2016 mengalami penurunan yang cukup banyak.

Hasil wawancara terhadap guru mata pelajaran ekonomi menunjukan bahwa penggunaan LKS belum digunakan secara maksimal, lembar kerja siswa hanya menjadi pegangan siswa, sebagai pemberian tugas, dan bahan evaluasi siswa. LKS masih digunakan secara konvensional. Guru hanya menjelaskan materi yang terdapat pada lembar kerja siswa tanpa mengembangkannya menggunakan strategi, metode, ataupun model pembelajaran yang ada. Guru masih berperan aktif dalam penggunaan LKS tanpa mengikutsertakan peransiswa. Untuk itu peneliti mencoba untuk mengembangkan lembar kerja siswa (LKS) menggunakan metode simulasi.

Rumusan masalah dalam penelitian adalah: 1) bagaimana proses pengembangan lembar kerja siswa dengan metode simulasi?, 2) bagaimana kelayakan lembar kerja siswa dengan metode simulasi menurut para ahli?, 3) bagaimanakah respon siswa terhadap penggunaan lembar kerja siswa dengan metode simulasi?. Berdasarkan rumusan masalah tersebut, tujuan dari penelitian ini adalah: 1) untuk mengetahui proses pengembangan lembar kerja siswa dengan metode simulasi, 2) untuk mengetahui kelayakan lembar kerja siswa dengan metode simulasi menurut para ahli, 3) untuk mengetahui respon siswa terhadap penggunaan lembar kerja siswa dengan metode simulasi. 


\section{METODE PENELITIAN}

Pada penelitian pengembangan ini bertujuan untuk menghasilkan sebuah produk berupa LKS dengan metode simulasi pada mata pelajaran ekonomi dengan materi perdagangan internasional untuk siswa kelas XI IPS semester genap serta untuk mengetahui pengaruh LKS dengan metode simulasi terhadap hasil belajar siswa. Tahap studi pengembangan model LKS dengan metode simulasi ini mengikuti prosedur dan langkah-langkah pengembangan model Borg \& Gall (Sugiyono, 2015: 37) yang sudah dimodifikasi, meliputi 7 langkah yaitu: 1) potensi masalah, 2) pengumpulan data, 3) desain produk, 4) validasi produk, 5) revisi produk, 6) uji coba produk, dan 7) produk akhir.

Subjek pada penelitian dan pengembangan ini adalah ahli materi, ahli bahasa, ahli media, dan siswa. Adapun jenis data dalam penelitian ini menggunakan data primer berupa hasil tes yang sudah dilakukan pada siswa dan data berupa saran serta masukan dari responden. Instrumen untuk pengambilan data menggunakan dua instrumen yaitu tes untuk mengetahui hasil belajar siswa dan angket validasi kelayakan serta respon siswa terhadap LKS. Teknik analisis data yang digunakan peneliti adalah uji t untuk uji hipotesisi nihil tentang perbedaan Mean dari dua sempel atau dua variabel (Yatim Riyanto, 1996: 105). Dalam penelitian ini peniliti menggunakan uji t untuk sampel yang sama dan variannya heterogen. Kemudian adapaun teknik analisis data deskriptif kuantitatif bertujuan untuk menghitung skala kelayakan dari LKS yang dikembangkan dengan metode simulasi.

\section{HASIL DAN PEMBAHASAN}

Berdasarkan analisis kebutuhan serta dilaksanakannya kurikulum 2013 yang mengacu pada keaktifan siswa, maka dipandang perlu suatu pembaharuan dalam proses pembelajaran ekonomi. Adapun proses tersebut yaitu dengan pendekatan, metode pembelajaran, dan sumber belajar yang dapat mengoptimalkan kemampuan siswa untuk meningkatkan hasil belajar ekonomi dengan cara mengembangkan LKS dengan metode simulasi.

Langkah-langkah desain produk pengembangan draft LKS dengan metode simulasi terdiri dari: 1) pendahuluan: kata pengantar, KI dan $\mathrm{KD}$, petunjuk pengunaan lembar kerja siswa, dan daftar isi, 2) isi/kegiatan belajar: peta konsep, judul, sub judul, materi, aktivitas siswa, rangkuman, dan uji kompetensi, 3) penutup: ulangan akhir semester, glosarium, dan daftar pustaka.

Tabel 2. Rekapitulasi Hasil Validasi LKS Oleh Ahli Materi

\begin{tabular}{llcc}
\hline \multicolumn{1}{c}{ Aspek Kelayakan } & Skor & Rata-rata \\
\hline A. & Cakupan Materi & 10 & 3,33 \\
\hline B. Akurasi Materi & 11 & 3,67 \\
\hline C. Kemutahiran dan Kontekstual & 11 & 3,67 \\
\hline D. Pendukung Penyajian Materi & 29 & 3,62 \\
\hline E. Kelengkapan Penyajian & 19 & 3,80 \\
\hline Total & 80 & 18,09 \\
\hline Rata-rata & & 3,62 \\
\hline
\end{tabular}




\begin{tabular}{ll}
\hline Kategori & Layak \\
Sumber: Data Penelitian Pengembangan yang Diolah &
\end{tabular}

Berdasarkan tabel 2 mengenai hasil data kuantitatif (skor validasi) ke data kualitatif (kategori nilai), diketahui bahwa rata-rata skor (X) 3,62 terletak pada rentang $3,41<\mathrm{X} \leq 4,21$ yang berarti lembar kerja siswa yang dikembangkan mendapat nilai "B" dengan kategori "Layak".

Tabel 3. Rekapitulasi Hasil Validasi LKS Oleh Ahli Bahasa

\begin{tabular}{llcc}
\hline \multicolumn{1}{c}{ Aspek Kelayakan } & Skor & Rata-rata \\
\hline A. & Kesesuaian dengan Perkembangan & 6 & 3,00 \\
& Peserta Didik & & \\
\hline B. & Keterbacaan & 3 & 3,00 \\
\hline C. & Kemampuan Untuk Memotivasi & 9 & 3,00 \\
\hline D. Kelugasan & 8 & 4,00 \\
\hline E. & Keruntunan Alur Pikir & 8 & 4,00 \\
\hline F. Kesesuaian dengan KBI & 6 & 3,00 \\
\hline G. Penggunaan Istilah dan Simbol & 11 & 3,67 \\
\hline Total & 51 & 23.67 \\
\hline Rata-rata & & 3,38 \\
\hline Kategori & & Cukup \\
\hline
\end{tabular}

Sumber: Data Penelitian Pengembangan yang Diolah

Berdasarkan tabel 3 mengenai hasil data kuantitatif (skor validasi) ke data kualitatif (kategori nilai), diketahui bahwa rata-rata skor (X) 3,38 terletak pada rentang 2,61<X $\leq 3,40$ yang berarti lembar kerja siswa yang dikembangkan mendapat nilai "C" dengan kategori "Cukup".

Tabel 4. Rekapitulasi Hasil Validasi LKS Oleh Ahli Desain

\begin{tabular}{lcc}
\hline \multicolumn{1}{c}{ Aspek Kelayakan } & Skor & Rata-rata \\
\hline A. Ukuran Buku & 6 & 3,00 \\
\hline B. Desain Kulit Buku & 34 & 3,09 \\
\hline C. Desain Isi Buku & 27 & 3,86 \\
\hline Total & 67 & 9,95 \\
\hline Rata-rata & & 3,32 \\
\hline Kategori & & Cukup
\end{tabular}

Sumber: Data Penelitian Pengembangan yang Diolah

Berdasarkan tabel 4 mengenai hasil data kuantitatif (skor validasi) ke data kualitatif (kategori nilai), diketahui bahwa rata-rata skor (X) 3,32 terletak pada rentang $2,61<\mathrm{X} \leq 3,40$ yang berarti lembar kerja siswa yang dikembangkan mendapat nilai "C" dengan kategori "Cukup".

Selama uji coba produk, rancangan sumber belajar yang telah dikembangkan diterapkan pada kondisi yang sebenarnya. Berdasarkan hasil uji coba diperoleh rekapitulasi sebagai berikut:

Tabel 5. Rekapitulasi Hasil Validasi LKS oleh Siswa Uji Coba

\begin{tabular}{lcccc}
\hline Aspek Kelayakan & $\begin{array}{c}\text { Jumlah } \\
\text { Skor }\end{array}$ & $\begin{array}{c}\text { Rata-rata } \\
\text { Skor }\end{array}$ & Nilai & Kategori \\
\hline 1. Materi & 101,43 & 4,41 & A & Sangat Layak \\
\hline
\end{tabular}




\begin{tabular}{lcccl}
\hline 2. $\quad$ Bahasa & 91,33 & 3,97 & B & Layak \\
\hline 3. Desain & 92,21 & 4,09 & B & Layak \\
\hline Total & 284,97 & 12,47 & - & - \\
\hline Rata-rata & & 4,16 & B & Layak \\
\hline
\end{tabular}

Sumber: Data Penelitian Pengembangan yang Diolah

Setelah lembar kerja siswa diketahui kelayakannya, peneliti mengukur peningkatan hasil belajar siswa yang telah dicapai. Data dikelola menggunakan SPSS versi 16 untuk mengetahui hasil statistik deskriptif, berikut adalah hasil data yang sudah dikelola:

Tabel 6. Hasil Olah Data Statistik Deskriptif

\begin{tabular}{lrrrr}
\hline \multicolumn{1}{c}{ Keterangan } & Mean & N & Std. Deviation & \multicolumn{1}{c}{$\begin{array}{c}\text { Std. Error } \\
\text { Mean }\end{array}$} \\
\hline SEBELUM & 77.8261 & 23 & 3.45953 & .72136 \\
\hline SESUDAH & 82.1739 & 23 & 15.10163 & 3.14891 \\
\hline
\end{tabular}

Sumber: Data Penelitian Pengembangan yang Diolah

Perhitungan rata-rata skor (Mean) mengalami peningkatan dari skor rata-rata sebelum 77,82 menjadi 82,17. Tabel paired differences menunjukkan bahwa $(\mathrm{p})=0,01$ $\leq 0,05$. Artinya, adanya pengaruh sebelum dan sesudah penggunaan lembar kerja siswa dengan metode simulasi.

Data peningkatan hasil belajar siswa didapatkan setelah peneliti melakukan uji coba kepada 23 siswa kelas XI IPS. Hasil belajar siswa awal didapatkan dari hasil belajar semester genap sebelum digunakannya lembar kerja siswa dengan metode simulasi.

Setelah dilakukannya pembelajaran tatap muka, pada pertemuan ketiga dilakukan evaluasi dengan memberikan siswa tes, soal tes terdiri dari 10 indikator kemampuan kognitif. Hasil belajar siswa sebelum dan sesudah penggunaan lembar kerja siswa dalam gambar 1 berikut:

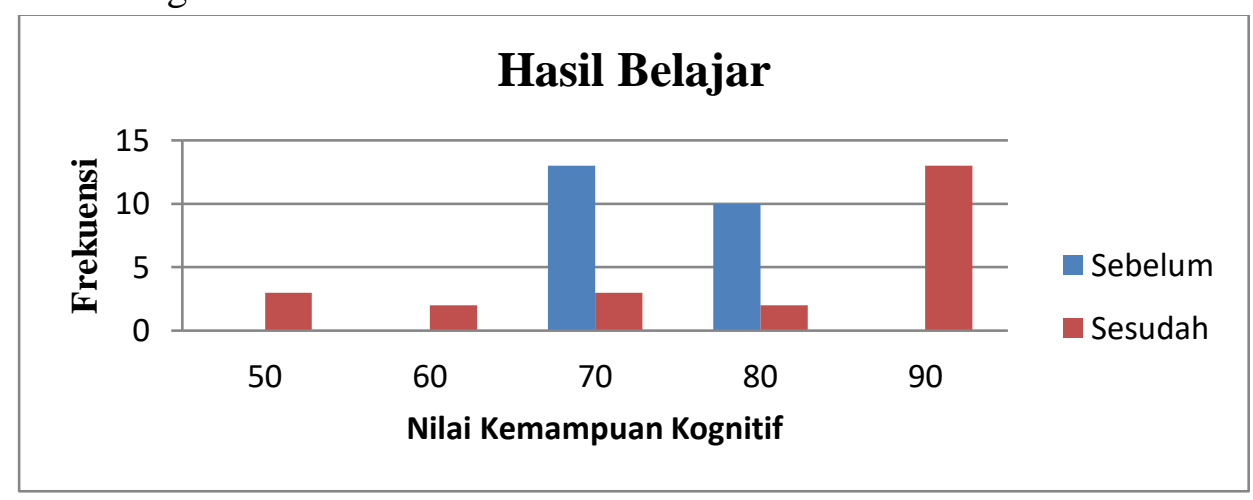

\section{Gambar 1. Frekuensi Nilai Sebelum \& Sesudah Menggunakan LKS Dengan Metode Simulasi}

Nilai rata-rata hasil belajar siswa sebelum menggunakan lembar kerja siswa adalah 77,82 dan sesudah penggunaan lembar kerja siswa sebesar 82,17, ini 
menunjukan adanya peningkatan nilai rata-rata setelah penggunaan lembar kerja siswa dengan metode simulasi.

Dari data tersebut kemudian dilakukan analisis menggunakan uji $\mathrm{t}$ untuk mengetahui pengaruhnya terhadap hasil belajar siswa. Hasil uji $t$ dua sempel berpasangan (paired sample $t$ tes), hasil yang diperoleh dapat dilihat pada tabel 6 berikut:

Tabel 7. Hasil Korelasi Uji t

\begin{tabular}{|c|c|c|c|c|c|c|}
\hline Keterangan & Mean & $\begin{array}{c}\text { Std. } \\
\text { Deviation }\end{array}$ & $\begin{array}{c}\text { Std. Error } \\
\text { Mean }\end{array}$ & $\mathrm{t}$ & $\mathrm{df}$ & $\begin{array}{l}\text { Sig. }(2- \\
\text { tailed }\end{array}$ \\
\hline SEBELUM - SESUDAH & -4.34783 & 15.04420 & 3.13693 & 2.386 & 22 & .018 \\
\hline
\end{tabular}

Sumber: Data Penelitian Pengembangan yang Diolah

Pada pengujian uji $\mathrm{t}$ diperoleh thitung sebesar 2,386. Sedangkan perhitungan tabel diperoleh sebesar 2,073 dengan df 22. Karena thitung $\geq$ tabel $(2,386 \geq 2,073)$ menunjukkan bahwa $\mathrm{H}_{0}$ ditolak dan $\mathrm{H}_{a}$ diterima. Hal ini menunjukkan pengembangan lembar kerja siswa dengan metode simulasi sebagai sumber belajar dan pengaruhnya terhadap hasil belajar siswa mata pelajaran ekonomi.

\section{KESIMPULAN}

Berdasarkan hasil penelitian pengembangan dan pembahasan, dapat disimpulkan bahwa:

1. Pengembangan lembar kerja siswa melalui tujuh tahap, yaitu: 1) potensi masalah, 2) pengumpulan data, 3) desain produk, 4) validasi produk, 5) revisi produk, 6) uji coba produk, 7) produk akhir.

2. Tingkat kelayakan lembar kerja siswa diketahui berdasarkan penilaian dari beberapa ahli, yaitu, penilaian kelayakan oleh ahli materi diperoleh rata-rata skor sebesar 3,62 yang termasuk dalam kategori Layak.Penilaian kelayakan oleh ahli bahasa diperoleh rata-rata skor sebesar 3,38 yang termasuk dalam kategori Cukup. Penilaian kelayakan oleh ahli desain diperoleh rata-rata skor sebesar 3,32 yang termasuk dalam kategori Cukup.

3. Respon siswa kelas XI IPS 1 dengan adanya lembar kerja siswa pada aspek kelayakan materi sebesar 4,41, bahasa sebesar 3,97, dan desain sebesar 4,09 menunjukkan perolehan rata-rata skor sebesar 4,16 yang termasuk dalam kategori Layak. Hasil uji t dua sempel berpasangan (paired sample $t$ tes) yang telah diolah dari hasil nilai belajar siswa diperoleh thitung sebesar 2386 dan tabel sebesar 2,073 atau thitung $\geq$ tabel $(2,386 \geq 2,073)$, hasil ini menunjukan bahwa Ho ditolak yang artinya 
pengembangan lembar kerja siswa dengan metode simulasi sebagai sumber belajar dan pengaruhnya tehadap hasil belajar siswa.

\section{DAFTAR PUSTAKA}

Agus Susilo, dkk. (2014). Pengembangan Modul Berbasis Pembelajaran Saintifik Untuk Peningkatan Kemampuan Mencipta Siswa Dalam Proses Pembelajaran Akuntansi Siswa Kelas XII SMA N I Slogohimo. Jurnal Pendidikan Ilmu Sosial, Volume 26, Nomor 1, hal. 50-56.

Asrul, dkk. (2014). Evaluasi Pembelajaran. Bandung: Ciptapustaka Media.

Astuti, D. S. (2010). Penggunaan Metode Belajar Numbered Head Together (NHT) Disertai Peta Konsep dan LKS Ditinjau Dari Motivasi dan Kreatvitas Siswa. Surakarta: Program PascaSarjana Pendidikan Biologi UNS.

Ernawati, dkk. (2016). Pengembangan Bahan Ajar Berbasis Adobe Flash Pada Pembelajaran Akuntansi Perusahaan Dagang Untuk Meningkatkan Prestasi Belajar Siswa SMK Negeri 1 Surakarta. Jurnal Tata Arta UNS, Volume 2, Nomor 2, hal. 1-15.

Fitri Nurhayati, dkk (2015). Pengembangan LKS Berbasis Problem Based Learning (PBL) Pokok Bahasan Tahap Pencatatan Akuntansi Perusahaan Jasa. Journal of Economic Education, Volume 4, Nomor 1, hal. 14-19.

Harun Rasyid, \& Mansur. (2011). Penilaian Hasil Belajar. Bandung: CV. Wacana Prima.

Kokom Komalasari. (2010). Pembelajaran Kontekstual Konsep dan Aplikasi. Bandung: PT. Refika Aditama.

Martinis Yamin. (2012). Desain Baru Pembelajaran Konstruktivitas. Jakarta: Referensi.

Nurul Mar'Atus Sholihah. (2015). Pengembangan Buku Saku Akuntansi Sebagai Media Pembelajaran Untuk Meningkatkan Motivasi Belajar Akuntansi Bagi Siswa Kelas XI Akuntansi Di SMK Muhammadiyah 2 Yogyakarta Tahun Ajaran 2014/2015. Yogyakarta: Program Pascasarjana Universitas Negreri Yogyakarta.

Sukardjo. (2005). Evaluasi Pembelajaran Semester 2. Yogyakarta: PPs UNY.

Sugiyono. (2015). Metode Penelitian \& Pengembangan Research and Development. Bandung: Alfabeta.

Sumiati, \& Asra. (2011). Metode Pembelajaran. Bandung: CV. Wacana Prima.

Suyono, \& Hariyanto. (2011). Beljar Dan Pembelajaran Teori Dan Konsep Dasar. Bandung: PT. Remaja Rosdakarya.

Tim Badan Standar Nasional Pendidikan. (2014). Instrumen Penilaian Buku Teks Pelajaran Tahun 2014. Diunduh di: http://bsnpindonesia.org/id/?p=1340, pada tanggal 14 Maret 2018.

Wina Sanjaya. (2006). Strategi Pembelajaran Berorientasi Standar Proses Pendidikan. Jakarta: Kencana Prenadamedia Group.

Yatim Riyanto. (1996). Metodologi Penelitian Pendidikan. Surabaya: SIC. 